\title{
Correction: More than just a mental stressor: psychological value of social distancing in COVID-19 mitigation through increased risk perception-a preliminary study in China
}

\author{
Yuanchao Gong (D), Linxiu Zhang \& Yan Sun (D)
}

Correction to: Humanities and Social Sciences Communications https://doi.org/10.1057/s41599-021-00774-1, published online 15 April 2021.

The original paper lacked a clear statement on ethical approval and informed consent. The following statements have now been added to the paper to provide additional clarity for the reader:

\section{Ethical approval}

Approval was obtained from the ethics committee of Institute of Psychology, Chinese Academy of Sciences. The procedures used in this study adhere to the tenets of the Declaration of Helsinki.

\section{Informed consent}

At the beginning of the questionnaire, we informed each participant of their rights and welfare, and committed to safeguarding their personal information. Only when participants gave permission to be part of this research would the survey proceed.

Published online: 15 November 2021

Open Access This article is licensed under a Creative Commons Attribution 4.0 International License, which permits use, sharing, adaptation, distribution and reproduction in any medium or format, as long as you give appropriate credit to the original author(s) and the source, provide a link to the Creative Commons license,
and indicate if changes were made. The images or other third party material in this article are included in the article's Creative Commons license, unless indicated otherwise in a credit line to the material. If material is not included in the article's Creative Commons license and your intended use is not permitted by statutory regulation or exceeds the permitted use, you will need to obtain permission directly from the copyright holder. To view a copy of this license, visit http://creativecommons.org/licenses/by/4.0/.

(๑) The Author(s) 2021 